\title{
Feeding rates of Calanoides carinatus: a comparison of five methods including evaluation of the gut fluorescence method
}

\author{
William Peterson ${ }^{1, *}$, Suzanne Painting ${ }^{2}$, Ray Barlow ${ }^{1, * *}$ \\ ${ }^{1}$ Zoology Department and Benguela Ecology Programme, University of Cape Town, Rondebosch 7700, South Africa \\ ${ }^{2}$ Sea Fisheries Research Institute, Private Bag X2, Roggebaai 8012, South Africa
}

\begin{abstract}
A comparison was made of ingestion rates of the copepod Calanoides carinatus estimated from the disappearance of chlorophyld (by fluorometry and HPLC), disappearance of cells, egg production, and from the gut fluorescence technique. Three measures of gut turnover time were also compared. Our primary goal was to determine whether the gut fluorescence method underestimated ingestion and if so, to determine if the problem was due (i) to pigment digestion or (ii) to incorrect estimates of gut passage time. Experiments used as food the diatom Thalassiosira weissflogii at 3

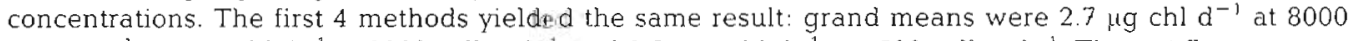
cells $\mathrm{ml}^{-1}, 1.5 \mu \mathrm{g} \mathrm{chl} \mathrm{d} \mathrm{d}^{-1}$ at 3000 cells ml $\mathrm{m}^{-1}$ and $0.84 \mu \mathrm{g} \mathrm{chl} \mathrm{d} \mathrm{d}^{-1}$ at $1500 \mathrm{cells} \mathrm{m} \mathrm{m}^{-1}$. The gut fluorescence

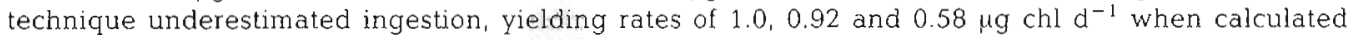
following the traditional approach of multiplying gut pigment content by gut evacuation rate (GER). The underestimate was not due to pigment digestion because pigment budgets showed that all pigment was accounted for, $106 \%$ on average. Thus we suggest that the problem was associated with using GER as a measure of gut passage time (GPT). GPT estimated from the GER was $16.7 \mathrm{~min}$, but when estimated from (i) measurements of fecal pellet poduction rates and from (ii) the ratio, pigment egestion rate/mean gut pigment content, results averaged $10.2 \mathrm{~min}$. Using this value, ingestion rates were equal to the other techniques at the intermediate and low food concentrations, and $80 \%$ of the other techniques at the high concentration
\end{abstract}

\section{INTRODUCTION}

Since its re-discovery in the 1980 's, the gut fluorescence technique (Nemoto 1968, Mackas \& Bohrer 1976. Dagg \& Wyman 1983) has been used widely to study feeding rates of herbivorous zooplankton both in the laboratory and in the sea. The technique has been particularly useful for the study of feeding rates in situ. With it, one avoids artifacts associated with lengthy incubations (Roman \& Rublee 1980) and with the use of electronic particle counters (Harbison \& McAlister 1980). The technique permits easy collection of data needed to calculate feeding rates of several species of herbivorous zooplankton collected simultaneously, thus allowing evaluation of food niche separation.

\footnotetext{
- Present address: Marine Sciences, SUNY, Stony Brook, New York 11794, USA

- Present address: 3 Carlton Terrace, Lipson, Plymouth, Devon, PL4 8PR, England
}

Studies of diel variations in feeding rate are simple to conduct as is investigation of the feeding impact of herbivorous zooplankton on a phytoplankton assemblage (e. g. Peterson et al. 1990).

Recently it has been suggested that the technique may not produce unbiased results. The method involves measurement of 2 parameters, gut pigment content $(G)$ and gut clearance rate constant $(\mathrm{k})$. The two are combined to yield an estimate of ingestion rate (I) as follows:

$$
\mathrm{I}=\mathrm{kG}
$$

with units of I, pigment ind. ${ }^{-1}$ time $^{-1} ; \mathrm{k}$, time ${ }^{-1}$; and $\mathrm{G}$, pigment ind. ${ }^{-1}$. It has been suggested that there may, at times, be significant amounts of pigment digestion such that any measurement of gut pigment content underestimates the actual gut pigment content (Conover et al. 1986, Lopez et al. 1988). Furthermore it is possible that $\mathrm{k}$ is underestimated by the conventional method of calculating the decline in gut pigment content $G$, with time for specimens held in filtered sea- 
water (Huntley et al. 1987). Thus, if either $\mathrm{k}$ or $\mathrm{G}$ (or both) are underestimated, ingestion rate will be underestimated.

In this study we set out firstly to measure copepod feeding rates using 5 different techniques, including the gut fluorescence method, in order to determine if measurements of gut pigment content, $G$, lead to underestimates of grazing rates. Secondly, we evaluated the problem of pigment digestion by constructing pigment budgets for the grazing experiments. Finally, we investigated the possibility that the gut evacuation rate constant, $k$, is a source of error by comparing gut passage times measured by 3 independent methods.

\section{METHODS}

Zooplankton was collected at a station $2 \mathrm{~km}$ offshore of Hout Bay, South Africa, by suspending a plankton net at a depth of $20 \mathrm{~m}$ and sampling for $5 \mathrm{~min}$ while the ship drifted. Copepods were returned to the laboratory in plastic buckets and adult female Calanoides carinatus sorted with wide-bore pipettes. The elapsed time between capture and sorting was 2 or $3 \mathrm{~h}$. After sorting, the copepods were fed the diatom Thalassiosira weissflogii at a concentration corresponding to the planned experimental concentration. Specimens were maintained at that concentration for at least $24 \mathrm{~h}$ before being used in an experiment.

Disappearance of chlorophyll and cells. For each experiment measurements of the disappearance of chlorophyll and cells were initiated as follows: a small amount of a culture of Thalassiosira weissflogii was added to a $20 \mathrm{l}$ bucket filled with $0.45 \mu \mathrm{m}$ filtered seawater, and the cell concentration was measured. Successive additions were made until the desired cell concentration was achieved. Then, triplicate measurements of cell concentration were made with the Coulter Multisizer and triplicate subsamples (50 and $250 \mathrm{ml}$ ) were filtered through GF/F filters for later determination of chlorophyll concentration by fluorometry and HPLC, respectively. Four or five $1.1 \mathrm{l}$ plastic bottles were filled with the food suspension and 4 or 5 female Calanoides carinatus were added to each bottle. The bottles were attached to a plankton wheel (1 rpm) and incubated in a $15^{\circ} \mathrm{C}$ room on a $13: 11 \mathrm{~h} \mathrm{light-dark} \mathrm{cycle}$ $\left(10 \mu \mathrm{E} \mathrm{m} \mathrm{m}^{-2} \mathrm{~s}^{-1}\right)$ for $24 \mathrm{~h}$. Two control bottles without copepods were set up for measurement of phytoplankton growth rates.

At the end of the incubation period, the water in each bottle was filtered through a 40 um Nitex nylon screen (to remove eggs, females and fecal pellets). Triplicate determinations were then made of chlorophyll a and phaeopigments by fluorometry (50 $\mathrm{ml}$ subsamples), of chlorophyll a by HPLC (200 $\mathrm{ml}$ subsamples) and of cell numbers in the filtrate, from each 'grazed' and 'control' bottle. Ingestion rates in terms of chlorophyll and cells were calculated following Frost's (1972) equations. Ingestion rates based on cell counts were converted to chlorophyll units by multiplying by the factor, chlorophyll cell ${ }^{-1}$, determined by dividing chlorophyll concentration (as measured by HPLC) by cell concentration (as measured by the Coulter Counter). The factor used was the mean of the $\mathrm{t}=0$ and $\mathrm{t}=24 \mathrm{~h}$ values of chlorophyll cell ${ }^{-1}$ (see Table 1).

A pigment budget based on the disappearance of chlorophyll measurements was calculated as follows: the amount of pigment (chlorophyll + phaeopigment) in the fecal pellets was compared to the amount of pigment ingested. Fecal pellets retained on the $40 \mu \mathrm{m}$ Nitex screen were rinsed into a small glass dish with filtered seawater, then filtered onto a GF/F filter. Pigment content was measured by fluorometry.

For all fluorometric chlorophyll determinations, filters were extracted in $10 \mathrm{ml}$ of $90 \% \mathrm{AR}$ acetone in centrifuge tubes, stored in the dark at $-20^{\circ} \mathrm{C}$ for $24 \mathrm{~h}$, then homogenized. The glass fiber/acetone slurry was centrifuged at $800 \times g$ for $10 \mathrm{~min}$. Fluorescence of the supernatant was measured using a Turner Designs Fluorometer before and after acidification with 2 drops of $10 \% \mathrm{HCl}$. Pigment concentrations were calculated as described in Dagg \& Walser (1987). This yields an estimate of the amount of pigment (chlorophyll + phaeopigment) in units of $\mu \mathrm{g}$ chlorophyll ind. ${ }^{-1}$, and does not include any correction for pigment digestion.

For chlorophyll analysis by HPLC, filtered algal samples were extracted immediately after filtration in $100 \%$ AR acetone by homogenisation, to minimise chlorophyllase activity (see Jeffrey \& Hallegraeff 1987). Chlorophyll a was separated from other pigments by reverse-phase HPLC on a Varian 5000 chromatograph using a modification of the method of Mantoura \& Llewellyn (1983): Solvent A was similar to that used by Mantoura \& Llewellyn while Solvent B consisted of $60 \%$ methanol and $40 \%$ acetone. Pigments were separated on a Beckmann Ultrasphere XL-C18, $3 \mu \mathrm{m}$ column $(4.6 \times 700 \mathrm{~mm})$ at a flow rate of $2 \mathrm{ml} \mathrm{min}^{-1}$ by gradient elution from $75 \% \mathrm{~A}: 25 \% \mathrm{~B}$, to $100 \% \mathrm{~B}$ in $5 \mathrm{~min}$, followed by an isocratic hold of $100 \% \mathrm{~B}$ for 4 min. Pigments were detected by absorbance at $440 \mathrm{~nm}$; chlorophyll a standard was purchased from Sigma (USA).

Egg production measurements. Five 1.1 l plastic bottles were filled with the seawater-diatom mixture and 2 female Calanoides carinatus added. The bottles were incubated on a plankton wheel as described above. After $24 \mathrm{~h}$ the water (containing eggs and females) in each bottle was filtered through a $60 \mu \mathrm{m} \mathrm{Nj}$ tex screen and the eggs counted immediately. Egg production measurements were converted to ingestion 
rates in terms of chlorophyll ingested using the following formula:

$$
I=\left[(E)\left(C_{E}\right)\right] /\left[(C: c h l)\left(K_{1}\right)\right]
$$

where $E=$ egg production rate (eggs female ${ }^{-1} \mathrm{~d}^{-1}$ ); $C_{E}$ = carbon content of an eggi $(\mathrm{C}: \mathrm{chl})=$ carbon: chlorophyll ratio; and $\mathrm{K}_{1}=$ gross efficiency of egg production. The carbon content of an egg was estimated by measuring egg diameter $(160 \mu \mathrm{m})$ then applying a carbon to volume conversion factor of 0.14 $\times 10^{-6} \mu \mathrm{g} \mathrm{C} \mu \mathrm{m}^{-3}$ to egg volume (Kiørboe et al. 1985). Carbon:chlorophyll ratios were obtained for each of the experiments by dividing carbon cell ${ }^{-1}$ by chlorophyll cell ${ }^{-1}$. Carbon cell ${ }^{-1}\left(=230 \mathrm{pg} \mathrm{C}\right.$ cell $\left.{ }^{-1}\right)$ was determined by measuring the protein, carbohydrate and lipid contents of Thalassiosira weissflogii, then converting each to carbon using conversion factors in Omori \& Ikeda (1984, p. 97). Methods for determination of biochemical composition were Lowry (for protein), phenol-sulfuric acid (for carbohydrates) and BlighDyer (for lipid); additional details will be presented elsewhere (Peterson, Barlow \& Huggett unpubl.).

In converting the egg production rate to chlorophyll ingestion rate, the gross efficiency of egg production $\left(K_{1}\right)$ was assumed to be 0.33 (from Kiørboe et al. 1985 , Peterson 1988). Though our measurements of ingestion (of phytoplankton cells) permitted calculation of the true $\mathrm{K}_{1}$, we used a constant factor of 0.33 so that the egg production rate represented an independent estimate of ingestion. As shown in Table 2, the true (= measured) $K_{1}$ was 0.35 , thus corroborating our assumption.

Gut fluorescence measurements. Female Calanoides carinatus were placed into $1 \mathrm{l}$ beakers or $1.1 \mathrm{l}$ bottles filled with the seawater-diatom mixture at a concentration of 4 or 5 individuals per container. Copepods in one beaker or bottle were sacrificed approximately every 2 h over a $24 \mathrm{~h}$ period, and females placed into a centrifuge tube with $10 \mathrm{ml}$ of $90 \%$ acetone. Tubes were stored in the dark at $-20^{\circ} \mathrm{C}$ for 24 to $48 \mathrm{~h}$, then centrifuged at $800 \times g$. Fluorescence before and after acidification was measured with the aid of a Turner Designs fluorometer. The amount of pigment ingested (I) over a $24 \mathrm{~h}$ period was calculated from:

$$
\mathrm{I}=\mathrm{kG}
$$

where $\mathrm{G}=$ mean gut pigment content per individual averaged for all observations at a given food concentration; $\mathrm{k}=$ gut evacuation rate in units of $\mathrm{d}^{-1}$.

Gut evacuation rate was measured by first allowing 20 to 30 females to feed for several hours, then removing them with a $500 \mu \mathrm{m}$ Nitex screen and rinsing them into a $5 \mathrm{l}$ beaker filled with $0.45 \mu \mathrm{m}$ filtered seawater. Two to 4 individuals were removed at $10 \mathrm{~min}$ intervals, over a $40 \mathrm{~min}$ experimental period, placed into centrifuge tubes with $10 \%$ acetone and processed as above. Gut evacuation rate $(\mathrm{k})$ was calculated from the relationship.

$$
G_{t}=G_{0} e^{-k t}
$$

where $\mathrm{G}=$ gut pigment content; $\mathrm{t}=$ time. Measurements were made at 1500 and 8000 cells ml-1.

Gut passage time was estimated in 2 ways. One, in a single experiment (at 3300 cells $\mathrm{ml}^{-1}$ of Thalassiosira weissflogii), 5 individual female Calanoides carinatus were incubated for $24 \mathrm{~h}$. The number of fecal pellets produced by each individual was determined by direct count and the mean time interval between production of fecal pellets calculated. Assuming that 2 pellets occur in the gut simultaneously, the gut passage time is then twice the time interval between the production of a single pellet. The other method (of Dagg \& Walser 1987) was to divide mean gut pigment content by hourly pigment egestion rate. Hourly pigment egestion rates were obtained by dividing the total amount of pigment found in the fecal pellets after $24 \mathrm{~h}$ (shown in Table 4), by 24.

\section{RESULTS}

Ingestion rates measured by the methods of disappearance of chlorophyll (by fluorometry and HPLC) and disappearance of cells are listed in Table 1. Within experiments (i. e. at a given food concentration), standard errors of the mean were usually between 5 and $20 \%$ of the mean and coefficients of variations ranged from 20 to $40 \%$. Agreement between techniques was excellent; mean ingestion rates calculated for each technique were within 4 to $13 \%$ of the mean of the 3 techniques combined.

Egg production rate data (Table 2) ranged from 75

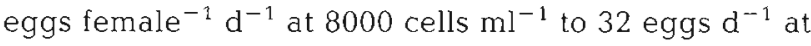
1500 cells $\mathrm{ml}^{-1}$. In units of carbon, egg production ranged from $22.4 \mu \mathrm{g} \mathrm{C}$ produced female $\mathrm{d}^{-1}$ at the highest food concentration ( $=45 \%$ of female body weight) to $9.5 \mu \mathrm{g} \mathrm{C}$ female ${ }^{-1} \mathrm{~d}^{-1}(=19 \%$ of body weight) at the lowest food concentration. The gross efficiency of egg production averaged 0.35 .

Changes in gut pigment content (GPC) vs time at each of the 3 cell concentrations are shown in Fig. 1. As expected GPC was highest at the highest food concentrations. There was little evidence of diel variation in GPC. Measurements of the gut evacuation rate constant averaged $0.0598 \mathrm{~min}^{-1}\left(\mathrm{R}^{2}=0.95\right.$ and $0.97, \mathrm{n}=5$ for both experiments). Ingestion rates calculated from the gut pigment content and evacuation rates were $1.11 \mu \mathrm{g}$ chl female ${ }^{-1} \mathrm{~d}^{-1}$ at 8000 cells $\mathrm{ml}^{-1}, 0.84$ at 3000 cells $\mathrm{ml}^{-1}$ and 0.64 at 1500 cells $\mathrm{ml}^{-1}$.

Results of all experiments are listed in Table 3 . Ingestion rates estimated from disappearance of chlorophyll and cells were the same as rates estimated from egg 
Table 1. Calanoides carinatus. Ingestion rates (ng chl a female ${ }^{-1} \mathrm{~h}^{-1}$ ), of copepods at 3 food concentrations, calculated from disappearance of chlorophyll and phytoplankton cells during $24 \mathrm{~h}$ laboratory incubations. Chlorophyll concentrations were measured by fluorometry and HPLC, and cells were counted on a Coulter Multisizer. Particle counts were converted from cells ${ }^{-1}$

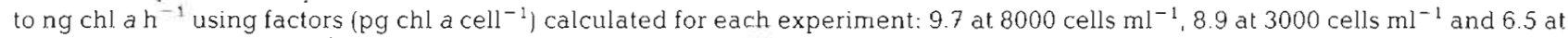
1500 cells $\mathrm{ml}^{-1}$. $\mathrm{S}_{\overline{\mathrm{x}}}$ : standard error of the mean; $\mathrm{CV}$ : coefficient of variation (= standard deviation/mean)

\begin{tabular}{|c|c|c|c|c|c|c|c|c|c|}
\hline \multirow[t]{2}{*}{ Bottle } & \multicolumn{3}{|c|}{8000 cells ml $^{-1}$} & \multicolumn{3}{|c|}{3000 cells ml $\mathrm{ml}^{-1}$} & \multicolumn{3}{|c|}{1500 cells $\mathrm{mi}^{-1}$} \\
\hline & Fluorometry & HPLC & Cell counts & Fluorometry & HPLC & Cell counts & Fluorometry & HPLC & Cell counts \\
\hline 1 & 165.6 & 232.5 & 126.3 & 78.3 & 57.2 & 49.4 & 49.2 & 44.8 & 48.5 \\
\hline 2 & 80.9 & 45.6 & 82.6 & 54.0 & 48.1 & 111.4 & 22.9 & 19.9 & 17.6 \\
\hline 3 & 87.1 & 142.8 & 127.6 & 51.9 & 48.5 & 44.7 & 22.9 & 40.7 & 20.1 \\
\hline 4 & 81.6 & 71.9 & 85.8 & 46.2 & 50.1 & 63.4 & 35.0 & 39.0 & 36.0 \\
\hline 5 & & & & & & & 47.7 & 39.0 & 43.1 \\
\hline Mean & 103.8 & 123.2 & 105.6 & 57.6 & 51.0 & 67.2 & 35.5 & 36.7 & 33.1 \\
\hline$S_{\bar{x}}$ & 20.65 & 41.82 & 12.36 & 7.09 & 2.12 & 15.25 & 5.72 & 4.33 & 6.14 \\
\hline$\hat{\mathrm{CV}}$ & 0.40 & 0.68 & 0.23 & 0.25 & 0.08 & 0.45 & 0.36 & 0.26 & 0.42 \\
\hline
\end{tabular}

Table 2. Calanoides carinatus. Summary of egg production data at the 3 experimental food concentrations. Units are eggs female ${ }^{-1} \mathrm{~d}^{-1} \mathrm{Egg}$ counts were converted to carbon units using a factor of $0.30 \mathrm{\mu g} \mathrm{C} \mathrm{egg}{ }^{-1}$ Carbon content of a female C. carinatus $\left(50 \mu \mathrm{g}\right.$ carbon female $\left.{ }^{-1}\right)$ was calculated as $40 \%$ of dry weight.

\begin{tabular}{|c|c|c|c|}
\hline Bottle & 8000 cells $\mathrm{ml}^{-1}$ & 3000 cells $\mathrm{ml}^{-1}$ & 1500 cells ml $^{-1}$ \\
\hline 1 & 77 & 52 & 37 \\
\hline 2 & 82 & 30 & 26 \\
\hline 3 & 79 & 47.3 & 0 \\
\hline 4 & 60 & 46 & 46 \\
\hline 5 & - & 23 & 50 \\
\hline 6 & - & 72.5 & - \\
\hline 7 & - & 66.5 & - \\
\hline 8 & - & 23 & - \\
\hline n (females) & 8 & 16 & 10 \\
\hline Mean (eggs fem ${ }^{-1} \mathrm{~d}^{-1}$ ) & 74.5 & 45.0 & 31.8 \\
\hline $\mathrm{S}_{\overline{\mathrm{x}}}$ & 4.94 & 6.64 & 8.96 \\
\hline Egg carbon $\left(\mu \mathrm{g} C\right.$ fem $\left.^{-1} \mathrm{~d}^{-1}\right)$ & 22.4 & 13.5 & 9.5 \\
\hline Ingested carbon ${ }^{a}$ ( $\mathrm{gg} \mathrm{C}$ fem. ${ }^{-1} \mathrm{~d}^{-1}$ ) & 63.3 & 36.2 & 29.6 \\
\hline Carbon:chlorophyll & 23.7 & 25.7 & 35.2 \\
\hline Gross efficiency of egg production $\left(K_{1}\right)$ & 0.35 & 0.37 & 0.32 \\
\hline
\end{tabular}

production measurements. Rates derived from gut fluorescence data were less than the other techniques. Differences were $41 \%$ of the grand mean at 8000 cells $\mathrm{ml}^{-1}, 58 \%$ at 3000 cells $\mathrm{ml}^{-1}$ and $76 \%$ at 1500 cells $\mathrm{ml}^{-1}$.

Pigment budgets (Table 4) showed that all of the pigment ingested during the grazing experiments was accounted for. When pigment egested was compared to pigment ingested on a per individual basis, $85 \%$ of the pigment ingested was accounted for at 8000 cells $\mathrm{ml}^{-1}, 100 \%$ at 3000 cells $\mathrm{ml}^{-1}$ and $133 \%$ at 1500 cells $\mathrm{ml}^{-1}$, an average of $106 \%$. When pigment in the grazed bottles (i.e. pigment in all remaining cells + pigment in fecal pellets) was compared to pigment in the control bottles after $24 \mathrm{~h}$, the result was 98, 95 and
$94 \%$ respectively (Table 4 ). Thus we conclude that chlorophyll a is not digested nor degraded to nonfluorescing molecules in the guts of Calanoides carinatus.

The shortfall between ingestion rates calculated from gut fluorescence data and ingestion rates estimated from the other 4 methods must result from incorrect. estimates of gut passage time rather than pigment digestion. The gut clearance rate constant used in our calculations, $0.0598 \mathrm{~min}^{-1}$, is equivalent to a gut passage time of $16.7 \mathrm{~min}(=1 / \mathrm{k})$. Based on the other 2 methods used to estimate gut passage time (discussed below), it would seem that this rate is too slow, by about $40 \%$.

By direct observation of defecation, we found that a 


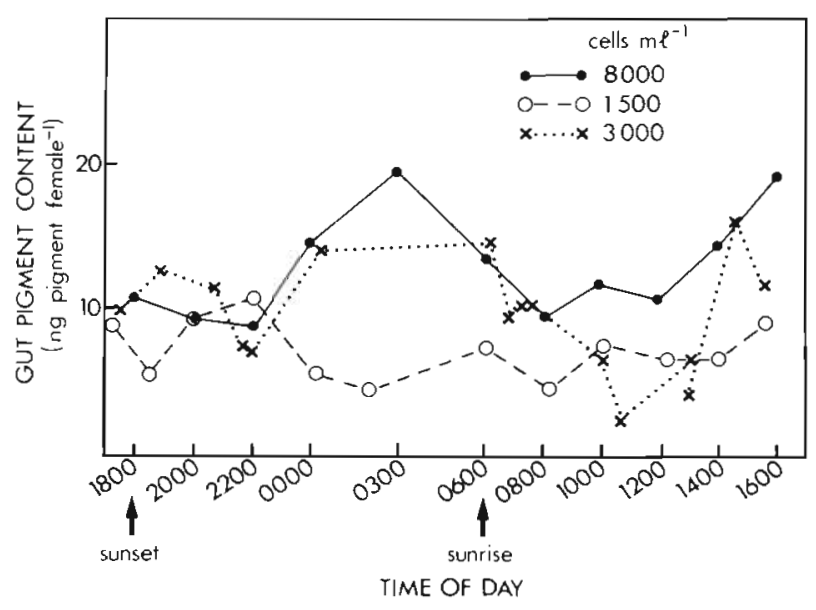

Fig. 1. Calanoides carinatus. Changes in gut pigment content as a function of time, for females feeding on the diatom Thalassiosira weissflogii at concentrations of 1500,3000 and 8000 cells ml-1 tent agreed better with those estimated from the other methods: 1.8 vs $2.7 \mu \mathrm{g}$ chl copepod ${ }^{-1} \mathrm{~d}^{-1}$ at 8000 cells $\mathrm{ml}^{-1}, 1.4$ vs 1.5 at 3000 cells ml $\mathrm{m}^{-1}$ and 1.0 vs 0.84 at 1500 cells $\mathrm{ml}^{-1}$. A shortfall remained only for the highest food concentration. In that experiment there could have been as much as a $15 \%$ pigment loss (Table 4) which would account for all but $19 \%$ of the pigment.

\section{DISCUSSION}

Excellent agreement was found between ingestion rate measured by disappearance of chlorophyll, disappearance of cells and from egg production data. Thus any of these techniques is suitable for estimation of daily ingestion rate for copepods in the laboratory as well as in the sea, as noted by Kiørboe et al. (1985) in their comparison of the same techniques. With respect

Table 3. Calanoides carinatus. Results of all ingestion rate measurements. Data are means of 4 or 5 experimental bottles including their corresponding standard errors $\left(S_{\bar{x}}\right)$. For most of the data listed, units of ingestion rate are $\mu \mathrm{g}$ chl a female $\mathrm{e}^{-1} \mathrm{~d}^{-1} \mathrm{For}$ gut pigment data, units are: ng chl a female ${ }^{-i}$ (mean gut pigment content, GPC), and $\mu \mathrm{g}$ chl a female ${ }^{-1} \mathrm{~d}^{-1}$ (pigment ingested). $\mathrm{K}_{1}=$ gross efficiency of egg production; a constant 0.33 was used in the calculations (see 'Methods')

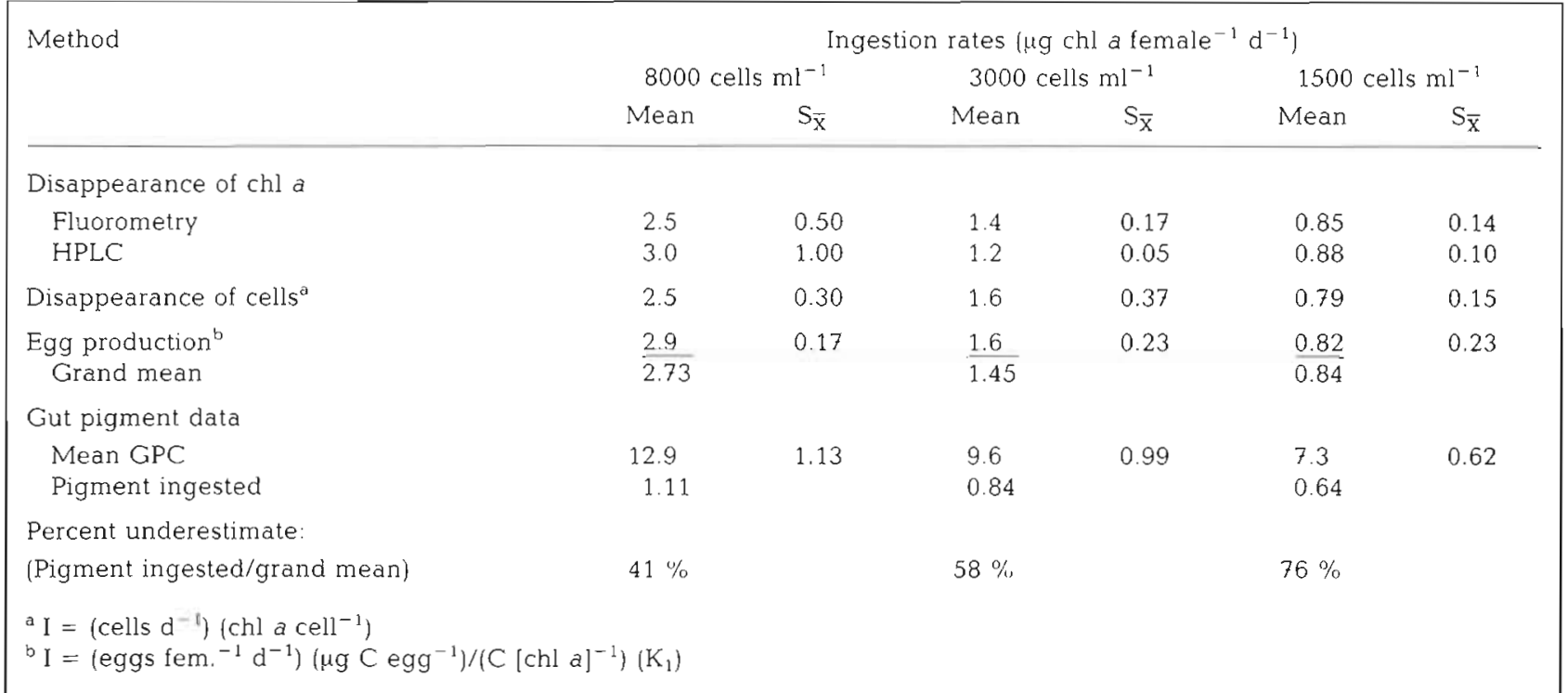

pellet appeared on average every $6.4 \mathrm{~min}$. If we assume that only 2 pellets are present in the gut at any time (pers. obs.; confirmed by Bautista et al. 1988) then the gut passage time for a pellet is twice $6.4 \mathrm{~min}$, or 12.8 min. Using Dagg \& Walser's (1987) method (in which the average gut pigment content is divided by the hourly egestion rates), gut passage times on the order of 9 min were calculated (Table 5). The overall mean of both methods was $10.2 \mathrm{~min}$.

When the gut passage time of 10.2 min (rather than $16.7 \mathrm{~min}$ ) was used as an estimate of gut evacuation rate, ingestion rates calculated from gut pigment con- to measurements of disappearance of chlorophyll, there was no reason to prefer use of an HPLC over fluorometry. Except for the experiment at 8000 cells $\mathrm{ml}^{-1}$, the standard errors associated with both instruments were small and about equal. In fact none of the 4 techniques showed a tendency to be more or less prone to error in our experiments.

The use of egg production data as a means of estimating ingestion rate is probably the most likely method to produce erroneous results. Egg production may not necessarily be an exact multiple of ingestion, especially if feeding and egg production are not in 
Table 4. Calanoides carinatus. (a) Comparison of pigment (chlorophyll + phaeopigment) ingestion (I) and egestion (E) rates for females. Units are $\mu \mathrm{g}$ pigment female $\mathrm{d}^{-1} . \mathrm{S}_{\overline{\mathrm{x}}}$ : standard error of the mean; CV: coefficient of variation. (b) Comparison of pigment in 'grazed bottles (pigment in phytoplankton cells + pigment in fecal pellets) and 'control' bottles (pigment in phytoplankton cells only) at the end of each $24 \mathrm{~h}$ experiment. The small amount of phaeopigment in the 'control' bottles was taken into account in the calculations. Units are $\mu \mathrm{g}$ pigment $\mathrm{l}^{-1}$

\begin{tabular}{|c|c|c|c|c|c|c|}
\hline \multirow[t]{2}{*}{ (a) } & \multicolumn{2}{|c|}{8000 cells $\mathrm{ml}^{-1}$} & \multicolumn{2}{|c|}{3000 cells ml $\mathrm{m}^{-1}$} & \multicolumn{2}{|c|}{1500 cells ml ${ }^{-1}$} \\
\hline & I & $E$ & I & $\mathrm{E}$ & I & $\mathrm{E}$ \\
\hline Mean & 2.49 & 2.11 & 1.39 & 1.39 & 0.85 & 1.13 \\
\hline $\mathrm{S}_{\overline{\mathrm{x}}}$ & 0.49 & 0.18 & 0.17 & 0.07 & 0.14 & 0.09 \\
\hline CV & 0.40 & 0.17 & 0.24 & 0.10 & 0.36 & 0.18 \\
\hline$E / I$ & & & & & & \\
\hline \multirow[t]{2}{*}{ (b) } & \multicolumn{2}{|c|}{8000 cells ml ${ }^{-1}$} & \multicolumn{2}{|c|}{3000 cells m.l $\mathrm{l}^{-1}$} & \multicolumn{2}{|c|}{1500 cells $\mathrm{ml}^{-1}$} \\
\hline & Grazed & Control & Grazed & Control & Grazed & Control \\
\hline Mean & 81.0 & 79.5 & 32.30 & 33.98 & 10.69 & 10.63 \\
\hline $\mathrm{S}_{\bar{X}}$ & 1.03 & 0.77 & 0.51 & 0.68 & 0.12 & 0.08 \\
\hline$\hat{C V}$ & 0.03 & 0.02 & 0.03 & 0.05 & 0.03 & 0.02 \\
\hline$G / C$ & \multicolumn{2}{|c|}{$102 \%$} & \multicolumn{2}{|c|}{$95 \%$} & \multicolumn{2}{|c|}{$100 \%$} \\
\hline
\end{tabular}

Table 5. Estimates of gut passage time, calculated from mean gut pigment content (GPC) divided by hourly egestion rate (Dagg \& Walser 1987). GPC values are listed in Table 3 ; hourly egestion rates are from data in Table 4

\begin{tabular}{|c|c|c|c|c|}
\hline $\begin{array}{l}\text { Food conc. } \\
\text { (cells } \mathrm{ml}^{-1} \text { ) }\end{array}$ & $\begin{array}{c}\text { Mean GPC } \\
\text { (ng female } \\
\text { (ng ) }\end{array}$ & $\begin{array}{c}\text { Egestion rate } \\
\left.\text { (ng female } \mathrm{h}^{-1} \mathrm{~h}^{-1}\right)\end{array}$ & (h) & $(\mathrm{min})$ \\
\hline 8000 & 12.9 & 87.9 & 0.147 & 8.8 \\
\hline 3000 & 9.6 & 57.9 & 0.166 & 9.9 \\
\hline 1500 & 7.3 & 47.1 & 0.155 & 9.3 \\
\hline
\end{tabular}

equilibrium. For example, for several species of Calanus which had been previously starved for a few days there was a several-day time lag between renewed feeding and resumption of egg production (Runge 1984, Peterson 1988, Attwood \& Peterson 1989). In our experiments females were fed Thalassiosira weissflogii at the experimental concentration for several days before being used in the experiments. The fact that the gross efficiency of egg production averaged $35 \%$, the 'expected' efficiency, suggests that the females were fully acclimated to the food supply.

Our suggestion that chlorophyll is not digested or reduced to inon-fluorescing molecules in copepod guts is in agreement with some workers but in stark contrast to others. Trivial losses were reported by Dagg \& Walser (1987), Kiørboe \& Tiselius (1987) and Pasternak \& Drits (1988): no more than $10 \%$ of ingested pigment was unaccounted for. The lack of any pigment digestion can be inferred from 2 other studies. First, in a study similar to ours, Kiorboe et al. (1985) compared several grazing techniques. In their study of 5 copepod species feeding in situ, the gut fluorescence technique gave the same result as did techniques based on chlorophyl, cells or egg production measurements, for Calanus finmarchicus, Acartia spp., Centropages hamatus and Pseudocalanus sp., but not for Temora longicornis. Second, Kiorboe et al. (1982) found good agreement between ingestion rates for $C$. hamatus estimated using gut fluorescence and disappearance of chlorophyll methods.

Two studies have reported extremely high losses: Conover et al. (1986), 95 \% loss, and Lopez et al. (1988), up to $92 \%$ loss. It has been suggested that there may have been methodological problems in the Conover study (Kiørboe \& Tiselius 1987). The Lopez study is difficult to evaluate because of extreme variability in their experiments: in 2 of 7 experiments there was no pigment loss but in 3 of 7 the losses were 69, 74, and $92 \%$ The mean of 7 experiments was $45 \%$ with a coefficient of variation of 0.81 . All other gut pigment studies which included some form of pigment budgeting reported an average loss of about $30 \%$ (reviewed in Dam \& Peterson 1988 and Lopez et al. 1988). Since the range in pigment loss is 0 to $95 \%$, we suggest that the degree of pigment digestion should be estimated routinely, by constructing pigment budgets. They can be prepared easily from measurements of ingestion using the method of disappearance of chlorophyll.

We concluded that gut pigment content data underestimated the true ingestion rate because of the man- 
ner in which gut passage times were estimated. The method most commonly used is to place a group of copepods with full guts in filtered seawater and monitor the decline in gut pigment content with time. This method provides a measure of the gut evacuation rate, and the inverse is assumed to be an estimate of gut turnover time, similar to gut passage time. The method does provide a measure of gut evacuation rate in the absence of feeding, but is it a measure of gut passage time for a copepod that is actively feeding? We suggest, as have others, that it is not. It seems reasonable to expect that the residence time of a packet of food in the gut will be shorter if a copepod is feeding than if it is not feeding. Assuming, on a time scale of minutes, a fairly continuous feeding rate, the rate at which food is consumed must be the same as the rate at which it is egested. Conversely, the rate of defecation of copepods held in filtered seawater is controlled solely by peristalsis. Thus it seems logical to assume that defecation rate will be slower in starved than in feeding animals. Some evidence for this is that Dagg \& Walser (1987) showed that gut passage time increased at progressively lower food concentrations. On the other hand, Ellis \& Small (1989) found no differences in gut evacuation rates among feeding and non-feeding female Calanus marshallae; thus the problem remains open for investigation.

Several other workers have suggested that the method of measuring gut clearance rate in filtered seawater leads to estimates of gut passage time that are too long. Kiørboe \& Tiselius (1987) showed that when Acartia tonsa were fed the alga Rhodomonas baltica and then transferred to feeding on the non-pigmented ciliate Oxyrhhis marina, the gut clearance rate, $\mathrm{k}$, was $0.048 \mathrm{~min}^{-1}$ as compared to $0.039 \mathrm{~min}^{-1}$ for copepods held in filtered seawater. The inverse of $\mathrm{k}$ was 20.8 vs 25.6 min respectively, a difference of $19 \%$

The value of gut evacuation rate constant obtained from gut clearance measurements is also dependent upon the length of time, $t$, over which an experiment is conducted. As $t$ approaches zero the value of $k$ increases greatly. There seems to be a growing consensus that $\mathrm{k}$ should only be estimated over the initial 30 min after placing the copepods in filtered seawater (see Dam \& Peterson 1988 for references). Our $k$ value was derived from measurements made over a $40 \mathrm{~min}$ period. We agree with the suggestion of Huntley et al. (1987) that one must take care to collect data at 2 min intervals over the initial 10 to $15 \mathrm{~min}$.

In conclusion, for adult female Calanoides carinatus, the gut fluorescence method, as traditionally applied, underestimated ingestion rates. The underestimate resulted from an overestimate of gut passage time (GPT) derived from gut evacuation measurements. When GPT was estimated from fecal pellet production rates and from the ratio, hourly pigment egestion rate/ mean gut pigment content, the mean (GPT) was 10.2 min, $37 \%$ faster than the estimate derived from measurements of gut evacuation rate. When the revised estimates of GPT were used to calculate ingestion rate, the result was the same as for the 4 other methods for the experiments conducted at 1500 and 3000 cells $\mathrm{ml}^{-1}$. The experiment at 8000 cells $\mathrm{ml}^{-1}$ underestimated the true ingestion by about $20 \%$. Thus we conclude that the gut fluorescence method continues to be a useful technique so long as attention is given to measurement of pigment digestion and to proper estimation of gut passage time.

Acknowledgements. We thank Deon Horstman for helping to collect the copepods, Ralph Ord for assistance with culturing the algae, and J. Huggett for assistance with some of the experiments. Tony van Dalsen drafted the figure. Financial support for W.T.P. and R.G.B. was provided by the Benguela Ecology Programme of the South African National Committee for Oceanographic Research. Discussions with and comments by H. Dam, J. Huggett, D. Armstrong and L. Hutchings greatly improved some of our arguments.

\section{LITERATURE CITED}

Attwood, C. G., Peterson, W. T (1989). Reduction in fecundity and lipids of the copepod Calanus australis (Brodskii) by strongly pulsed upwelling. J. exp. mar Biol, Ecol. 129: 121-131

Bautista, B., Rodriguez, V Jimenez, F. (1988). Short-term feeding rates of Acartia grani in natural conditions: diurnal variations. J. Plankton Res. 10: 907-920

Conover, R. J., Durvasula, R., Roy, S., Wang, R. (1986). Probable loss of chlorophyll-derived pigments during passage through the gut of zooplankton, and some of the consequences. Limnol. Oceanogr. 31: 878-887

Dagg, M. J., Walser, W. E. (1987). Ingestion, gut passage, and egestion by the copepod Neocalanus plumchrus in the laboratory and in the subarctic Pacific Ocean. Limnol. Oceanogr. 32: 178-188

Dagg, M. J., Wyman, K. (1983). Natural ingestion rates of the copepods Neocalanus plumchrus and $N$. cristatus calculated from gut contents. Mar. Ecol. Prog. Ser. 13: 37-46

Dam, H. G., Peterson, W. T (1988). The effect of temperature on the gut clearance rate constant of planktonic copepods. J. exp. Mar. Biol. Ecol. 123: 1-14

Ellis, S. G., Small, L. F. (1989). Comparison of gut-evacuation rates of feeding and non-feeding Calanus marshallae. Mar. Biol. 103: 175-181

Frost, B. W. (1972). Effects of size and concentration of food particles on the feeding behavior of the marine planktonic copepod Calanus pacificus. Limnol. Oceanogr. 8: 805-815

Harbison, G. R., McAlister, V. L. (1980). Fact and artifact in copepod feeding experiments. Limnol. Oceanogr. 25: 971-981

Huntley, M. E., Marin, V., Escritor, F. (1987). Zooplankton grazers as transformers of ocean optics: a dynamic model. J. mar. Res. 45: 911-945

Jeffrey. S. M., Hallegraeff, G. M. (1987). Chlorophyllase distribution in ten classes of phytoplankton: a problem for chlorophyll analysis. Mar. Ecol. Prog. Ser. 35: 293-304 
Kiørboe, T., Mohlenberg, F., Nicolajsen, H. (1982). Ingestion rate and gut clearance in the planktonic copepod Centropages hamatus (Lilljeborg) in relation to food concentration and temperature. Ophelia 21: 181-194

Kiørboe, T., Mohlenberg, F., Riisgård, H. U. (1985). In situ feeding rates of planktonic copepods: a comparison of four methods. J. exp. mar. Biol. Ecol. 88: 67-81

Kiorboe, T., Tiselius, P. T. (1987). Gut clearance and pigment destruction in a herbivorous copepod, Acartia tonsa, and the determination of in situ grazing rates. J. Plankton Res. 9: $525-534$

Lopez, M. D. G., Huntley, M. E., Sykes, P. E. (1988). Pigment destruction by Calanus pacificus: impact on the estimation of water column fluxes. J. Plankton Res. 10: 715-734

Mackas, D., Bohrer, R. (1976). Fluorescence analysis of zooplankton gut contents and an investigation of diel feeding patterns. J. exp. mar. Biol. Ecol. 25: 77-85

Mantoura, R. F. C., Llewellyn, C. A. (1983). The rapid determination of algal chlorophyll and carotenoid pigments and their breakdown products in natural waters by reversephase high performance liquid chromatography. Analytica Chim. Acta 151. 297-314

This article was presented by Dr T Kiorboe, Charlottenlund, Denmark
Nemoto, T (1968). Chlorophyll pigment in the stomach of euphausiids. J. Oceanogr. Soc. Japan 24: 253-260

Omori, M. Ikeda, T (1984). Methods in marine zooplankton ecology. John Wiley and Sons, New York

Pasternak, A. F., Drits, A. V (1988). Possible degredation of chlorophyll-derived pigments during gut passage of herbivorous copepods. Mar. Ecol. Prog. Ser 49: 187-190

Peterson, W. T (1988). Rates of egg production by the copepod Calanus marshallae in the laboratory and in the sea off Oregon, USA. Mar. Ecol. Prog. Ser. 47:229-237

Peterson, W. T., Painting, S., Hutchings, L. (1990), Diel variations in gut pigment content, diel vertical migration and estimates of grazing impact for copepods in the southern Benguela upwelling region, in October $1987 \mathrm{~J}$. Plankton Res. 12 (in press)

Roman, M. R., Rublee, P. A. (1980). Containment effects in copepod grazing experiments: a plea to end the black box approach. Limnol. Oceanogr. 25: 982-990

Runge, J. A. (1984). Egg production of the marine planktonic copepod, Calanus pacificus Brodsky: laboratory observations. J. exp. mar. Biol. Ecol. 74: 53-66

Manuscript first received: October 31, 1989 Revised version accepted: February 1, 1990 